\title{
Assessment of Beef Cattle Production, Slaughtering and Marketing Practice in Haramaya University, Ethiopia
}

\author{
Birmaduma Gadisa ${ }^{1, ~ *, ~ G e m e c h u ~ T a f f a ~}{ }^{2}$ \\ ${ }^{1}$ Oromia Agricultural Research Institute, Mechara Agricultural Research Center, Mechara, Ethiopia \\ ${ }^{2}$ School of Animal and Rangeland Sciences, Haramaya University, Dire Dawa, Ethiopia
}

Email address:

birmaduga@gmail.com (B. Gadisa)

${ }^{*}$ Corresponding author

\section{To cite this article:}

Birmaduma Gadisa, Gemechu Taffa. Assessment of Beef Cattle Production, Slaughtering and Marketing Practice in Haramaya University, Ethiopia. World Journal of Food Science and Technology. Vol. 3, No. 2, 2019, pp. 26-31. doi: 10.11648/j.wjfst.20190302.12

Received: June 11, 2019; Accepted: July 10, 2019; Published: August 10, 2019

\begin{abstract}
Ethiopia is endowed with good livestock production potential; however, the product utilization was underutilized. Meat is one of the most nutritious animal source foods that humans can consume. In Ethiopia, domestic consumption requirements for red meat arise due to rapidly growing population, increasing urbanization, rising income, increase export of live animal and meat to generate foreign exchange earnings. This study was anticipated to asses beef fattening, processing, handling and marketing of meat and live animal in the Haramaya University, which is found in Ethiopia, and known for technology innovation, adoption, and transfer for community. The source of cattle for fattening in the university is from Tullu Dambir, Haramaya and Oda Bultum cooperatives based on weight. Sex, appearance, and weight have limitation during buying. The farm was selected only male greater than $225 \mathrm{~kg}$ and good appearance. As cattle enter the farm identification number, vaccination, and quarantine for 15 days applied. The major feed resource for fatting was hay, silage, cafeterias leftover, and kitchen by-product. The cattle have managed in-group as a time entering to the fattening for 100 days. There was no live animal selling in farm. Even though there has been plenty of knowledge and experience in the University there is yet poor slaughterhouse management and traditional slaughtering practice. There was no compartment lairage, electrical hoist, vehicle, separated room for stomach, waste collection room, carcass classification, carcass chilling room, laboratory, refrigerator, stunning pen, chilling room, hide processing room and sterilization facilities. The University enterprise has been retailing the meat with $80 \mathrm{~kg} / \mathrm{birr}$ for student cafeteria service and $100 \mathrm{~kg} / \mathrm{birr}$ for staff restaurant and individual/ private restaurants as well as individual campus resident. The fattening station and the abattoir should work in collaboration with the scientific communities to supply quality beef.
\end{abstract}

Keywords: Abattoir, Ethiopia, Haramaya University, Beef Cattle Production

\section{Introduction}

Ethiopia is endowed with good livestock production potential mainly due to diversified natural resource availability, climate, and large populations of different livestock species [1]. The CSA, 2016/17 report indicated that Ethiopia had estimated (in million) population of 57.83 cattle, 28. 89 sheep, 29.70 goat, 60.51 poultry, 2.08 horses, 7.88 donkeys, 0.41 mules, 1.23 camels. This sector plays vital role in supply of meat, milk, hide and skin, wool, egg and as a source of additional income both for smallholder and for pre-urban farmers [2]. Meat is one of the most nutritious foods that humans can consume, particularly in terms of supplying high quality protein (amino acids), minerals (iron) and essential vitamins like B12, D and K. In Ethiopia, domestic consumption requirements for red meat was arise due to rapidly growing population, increasing urbanization, rising income, increase export of live animal and meat to generate foreign currency [3].

Increased demand for beef will develop the market channel for beef. In recent years, feedlot firms are flourishing and being engage for local and export of processed meat and live animals. Improved quality will stimulate beef consumption [4]. Meat quality is becoming more important as consumers 
worldwide are increasingly demanding consistently higher quality meat [5]. Which is because of beef industry is better is in dealing with conversion and processing of live animals to different products and by products [6].

Haramaya University (HU) community engagement enterprise development, under community service and the school of animal and range science have different established demonstrations and research farms viz., Beef, Dairy, Goat, Sheep, Swine, Poultry and Apiculture to provided trainings to farmers and development workers, on-farm demonstrations through academic study's out comes. In addition to these demonstration farms, "one hundred days" beef fattening station is the one that established with the aim of availing the access of red and cooked meat for community in the campus. This station had long history in this campus, however unforeseen things are yet available in the way of cattle production and slaughtering, carcass handling and market system are traditional and incomparable with University history as country and in Eastern Africa. Similarly, according to the [7] report, Ethiopian meat production and marketing has been plagued due to lack of quality, sanitation, disease, and unqualified meat production process. Therefore, this manuscript was planned to assess beef fattening, processing, handling and marketing of meat and live animal in the University.

\section{Materials and Methods}

\subsection{Description of Study Area}

The study was conducted at Haramaya University," one hundred days" beef fattening station. The University is located 17, 40, and $510 \mathrm{~km}$ from Harar, Dire Dawa and Addis Ababa. The beef fattening station, located at $0925^{\prime} 11705^{\prime \prime} \mathrm{N}$; 042o 01 '56 387"E; 2019 m.a.s.l. altitude and receives 780mm mean annual rainfall. The mean annual minimum and maximum temperatures are 8.5 and 24.4 , respectively [8].

\subsection{Sampling and Data Collection}

A beef fattening station was purposively selected, station visit and survey (pre-designed questionnaires') made to asses beef cattle production system, fattening program, feed resource availability and feeding system, housing facilities, identification available resource, live animal marketing practice after finishing, abattoir operation, post slaughter and beef marketing in the campus.

\subsection{Feed Analysis}

Feed used in experiment was analyzed at Haramaya University Animal Nutrition laboratory. The samples were analysed for proximate (DM, Ash, CP) and detergent fibre (NDF, ADF)analyses. DM and nitrogen $(\mathrm{N})$ were analysed according to the standard methods of [9], whereas NDF and $\mathrm{ADF}$ were determined by the methods of [10].

\section{Results and Discussion}

\subsection{Source of Cattle}

The assessment result in current study revealed there was no nearby market for the delivery of animal for fattening station. Therefore, the animals were obtained from cooperatives, who brought these beef cattle from other districts, zones and regions. The source of cattle are only from cooperatives for the fattening station namely; TulluDambir, Haramaya and Oda Bultum Union from Meta, Haramaya and Oda Bultum districts, respectively. In contract to that [11] report that commercial feedlot operation purchased animals for fattening purpose from different opened local market. This observation is a good experience in beef cattle value chain map for other institution and proximity cooperatives. Soon as the cooperative brought the animal via the means of transportation viz., trucking and vehicle to the station, identification number (ear tag) had given for each bull. However, these animals are collected from different locations (market) by known cooperative, their specific breed and history is hither to unknown. This resulted difference between animal in feed conversion efficiency, dressing percentage and prolong the fatting time at the station might be needed for compensatory growth.

\subsection{Selection Criteria to Purchase Cattle}

The Haramaya University community engagement and enterprise development is mandated office to set criteria and purchase bulls from cooperative in a legal form; and finally the senate of the University were approved the criteria. The focus of criterion to purchase animals are limited to weight, appearance, sex, and exhibited unable to address the age, breed, and history of each animals to be included. However, breed and age is a most important criterion for selection of beef cattle fattening operators due to link with feed conversion efficiency and meat quality sources [11].

Weight: it was one of those criteria set for purchasing and the cattle were bought from cooperative only by weight bases. However, in most of terminal market in Ethiopia weighing based price not practiced [12-15], rather marketing is based on visual observation on body condition and approximation of age and sex (Getachew et al., 2010). The weight based criteria in current study revealed as if the weight of animal is less than $200 \mathrm{~kg}$ unaccepted; between $200-225 \mathrm{kgaccept}$ about $30 \%$ out of availed population; and greater $225 \mathrm{~kg} 70 \%$ accepted (source: farm guide).

Appearance and sex: the application of this criterion is to select horned, blinded, abnormal legs, and damages in bulls and rejected by the enterprise for fattening. Only male animals with good physical appearance selected for fattening. The current assessment observed that, there was no age restriction, the condition which should not be neglected in the criteria, since the quality of meat is affected by the age of the animal. Consumer's satisfaction is primarily based on tenderness, juiciness, flavor, color and appearances. These all eating qualities affected by age of animals particular 
tenderness $[16,17]$ decreases as animal become matured. The older animals are usually source of tough meat source [18].

\subsection{Animal Transportation}

Transportation of live cattle by the cooperative was using smaller vehicle, the cooperatives in use sloppy land to loading and unloading on vehicle, which is non-conventional for higher animal and interferes their welfare. Similarly, report by [19] who vehicle (Isuzu) common means of transport for cattle from Ambo to Kera market. However, Warriss [20] reported that transportation involves a series of handling and confinement situations, which can lead to suffering for stress. Stress causes changes in the immune system mainly due to physiological changes [21. Such changes leads to increased heart rate, respiratory rate, weight loss, depletion of muscle glycogen reserves, which may result in a higher ultimate meat $\mathrm{pH}$, greater water holding capacity, tougher meat, darker meat color and injury even to death $[22,21]$.

\subsection{Precondition Before Cattle Entrance to the Farm}

The cattle were given an ID number for identification, weighed for cost determination and to kwon the initial weight of bull, Anti-parasite application to deworm internal parasite and quarantined. Isolation of all purchased animals on arrival at the farm for a minimum period of two to three weeks in isolation facility to observe for clinical signs of disease and conduct any necessary tests and treatments. These practices are supported with [23] who reported that isolate all purchased animals on arrival at your farm for a minimum period of 28 days in your isolation facility important for farm biosecurity.

\subsection{Feed and Feeding}

Major feed input in farm (Table 1) were hay, silage, cafeterias left over and industrial by-products. Additionally, kitchen by products like Cabbage trim, Potato trim, peapod were used throughout the year in feedlot. Since the availability of cafeterias left over is high in Haramaya University it's the major beef cattle feed resource in station. However, silage, hay and industrial by product is more allocated for dairy cattle in campus.

Table 1. Feed type used in Haramaya University Beef fattening station.

\begin{tabular}{ll}
\hline Feed resource & \\
\hline Preserved cafe left over & Peapod \\
Wheat straw & Wheat bran with maize \\
Cabbage trim & Brewery grain \\
Potato trim & Potato \\
Oat straw & Wheat bran \\
Milling byproduct & Nugcake \\
Hay & Wheat short \\
Silage & Maize and Sorghum \\
\hline
\end{tabular}

Source: Haramaya University beef farm.

\subsection{Chemical Composition of Feed}

According Gemechu [24] the concentrate supplement for the beef in the farm is dried cafeteria leftover (DCLO), the leftover is transported and naturally dried from three times daily collections (breakfast, lunch, and dinner times). The nutritional compassion (Table 2) of these DCLO has different nutritional composition at different mealtime of the day. As observed in the farm feeding system and management is too poor and this could be causes for lower the quality of beefMost of this feed ingredients (Table 1) used in this farm has high moisture content and some would combined then fermented finally could result yeast and mold development, unless they first properly dried. Yeast and mold development could causes undesirable flavor on final product meat. This result was supported by [25] who reported that natural pasture grazed animal had good aroma score than animal finished in feedlot.

Table 2. Proximate composition of fresh Cafeteria food left over.

\begin{tabular}{|c|c|c|c|c|c|c|c|}
\hline Feed type & DM\% & Ash\% & $\mathrm{CP} \%$ & EE\% & CF\% & NDF $\%$ & ADF $\%$ \\
\hline Concentrate & 91.8 & 9.54 & 20.04 & 9.74 & 54.4 & - & - \\
\hline Break fast & 91.94 & 1.87 & 8.42 & 2.52 & 0.26 & - & - \\
\hline Lunch & 92.41 & 3.71 & 11.38 & 6.71 & 0.85 & - & - \\
\hline Dinner & 92.53 & 3.67 & 10.01 & 7.76 & 0.92 & - & - \\
\hline Hay & 95.45 & 8.93 & 6.71 & 1.28 & - & 80.51 & 52.84 \\
\hline Corn Silage & 94.96 & 7.66 & 7.76 & 2.4 & - & 75.00 & 41.00 \\
\hline
\end{tabular}

$\mathrm{DM}=$ Dry Matter, $\mathrm{CP}=$ Crude Protein, $\mathrm{EE}=$ Ether extract, $\mathrm{CF}=$ Crude fibber.

\subsection{Fattening Program and Animal Management System}

In the station, cattle are managed in-group. During remain for one hundred days, the second weighing was once practiced after quarantine; to know the initial body weight, to begin fattening program and be aware of development of animal monthly. In the station, even though started fattening program the animal had not obtained formulated feed as stage and time of feed requirements. Zgajnar and Kavcic [26] reports that's feed formulation in beef farms was used for precise management to achieve economically justified outcome. High moisture containing feeds like cafeteria leftover might affect meat eating quality particular on flavor. The content and nature of the precursors present in the meat are affected by several factors including genetics, feed, handling of the live animals and subsequent handling of the meat [27]. In addition to this cafeteria leftover untreated crop residue collected from crop research farm of Haramaya university and hay, purchased from Sululta (about $600 \mathrm{~km}$ far from the base of the farm) used as feed source. Higher plane of nutrition promotes earlier fattening while a lower level results in a delayed or slower fattening process. 
Housing for animal was only shade to protect only sun direction from West to East. There was no critical health problem observed. After 100 day the cattle was took to slaughter house. There was no final body weight records were practiced. Therefore, it was difficult to analysis partial budget analyses and where the farm or this station stands (profit or debit).

\subsection{Live Animal Marketing Practice After Finishing and Slaughtering}

There was no live animal sold in farm for University community or other community around the campus. The cattle in beef farm were only to slaughtered house in the University. Even though there has been plenty of knowledge and experience in the University there was yet poor slaughterhouse management and slaughtering practice. Slaughter practices and storage facilities affect the sanitary status of meat and may limit its value in domestic and international trade [28].

It is important to take note that consumers worldwide always demand to have their foods of higher standards or better quality [29]. Haramaya University beef farm also have abattoir for slaughter, but there is no precondition for slaughter like conditions cattle pre-slaughter, compartment lairage, stunning pen, stunning equipment, data record sheet in abattoir. According to FAO [30] guideline scientific research has shown that warm-blooded animals (includes livestock) feel pain and the emotion of fear. Fear and pain are very strong causes of stress in livestock and affects the quality of meat. Efficient, experienced, and quiet handling of livestock, using recommended techniques and facilities, as well as taking measures to eliminate pain and accidental injury, will reduce stress in the animals and prevent quality deficiencies in meat and by-products. This result was supported by [31] who reported that stressed animal in the pre-slaughter was resulted rapid release of enzymes, cortisols and catecholamines which may lead to depletion of glycogen, high meat ultimate $\mathrm{pH}(\mathrm{pHu})$ and dark cuts.

Equipment used for slaughtering were not updated, the abattoir uses hammer and Axes for stunning purposes, which make animal suffer for more pain. Injuries such as torn and hemorrhagic muscles and broken bones, caused during handling, transport and penning, considerably reduce the carcass value because the injured parts were condemned. If secondary bacterial infection occurs in those wounds, this causes abscess formation and septicemia and the entire carcass might be condemned [30].

The house hygiene was not good and well managed during our observation, water scarcity, and trims (head, leg, skin) of previously slaughtered animal was not properly cleaned from floor. Waste disposal mechanism was also seen as poor disposing practice: they simply dump the viscera outside the abattoir. Therefore, vultures (birds) and for kids from outside the University come and collect for dog but these waste could be resource which could be processed further and utilizes for poultry or pet food which was untried in this big institution. The slaughtering process in this slaughterhouse does not care about the quality of skin and meat, the abattoir workers was operated on the floor and hit the bone to break over the skin and trample the meat with dirt boat.

\subsection{Operation and Facilities of the Abattoir}

Haramaya University abattoir was small scale, establish only for the community service slaughter up to 30-50 animals per day. Slaughtering service regularly in the morning times from 6:00 AM to 7:30 AM. The stunning method was commonly practiced by hammer on atlantooccipital space. The abattoir workers in the abattoirs have been no incentives for regular checkup and treatment facilities. This was a critical issue, which needs urgent remedial measures. Without the workers' health guarantee, enough skill and knowledge of abattoir workers, it is difficult to ensure food safety of the animal products. Cortosi [32] strongly recommended that the local authorities should grant a license for abattoir workers to attain the required standard carcass dressing qualification. Similarly, FAO [33] recommended regular and periodic training for abattoir workers to maintain sound sanitary, safe meat hygiene, and gear forward the technical operation efficiency in the sector.

There were no full facilities in the abattoirs only lairage, different class, manual hoist and electric. The abattoirs carry out slaughter mostly on floor because manual hoist was needed force. There was no compartment lairage, functional electrical hoist, vehicle, separated room for stomach, waste collected room, carcass classification, carcass chilling room, laboratory, refrigerator, stunning pen, chilling room, hide processing room and sterilization facilities. However, demonstration equipment in abattoir should not only be limited to genuine slaughter facilities but also include equipment for humane killing of slaughter animal as well as treat plants solid abattoir wastes and effluent in order improve environmental impact of abattoirs [33].

Currently, meat is transported from abattoirs to the restaurant (staffs and students lounges) by any vehicle available around and there is no specified meat transporting van truck. Because of the abattoir had not own vehicle that takes regular service for carcass transportation. It might be causes for carcasses disposed to contamination. The University should be considered this constraint to solve because transportation and storage are vital links in meat hygiene and safety, effective control measures are essential at each point to prevent contamination [34]. Many microorganisms stick very firmly to surfaces, in tiny almost invisible layers of organic materials, so called biofilms. Inactivation of those microorganisms requires antimicrobial treatments, carried out in food industries through hot water or steam or through the application of disinfectants. Disinfectants are chemical substances, which kill microorganisms but should not affect human health through hazardous residues and not cause corrosion of equipment. Food production premises are regularly subjected to cleaning and disinfection $(\mathrm{C} \& \mathrm{D})$ regimes designed to reduce bacterial load and eliminate pathogens [35].

The overall abattoirs sanitary were below the requirements 
of good hygiene practices (GHP) in slaughterhouses. This lack of the required instrumentation and facilities in the abattoirs, less attention from the administration, and less researches carried out on meat quality and abattoir functionality management. However, Ethiopian Minister of Agriculture has the proclamation on the issue of meat inspection No 81/1976 to determine livestock and livestock product (LLP) as fit for human consumption, classification, and database management. Fortunately, in abattoirs, ante and postmortem carcass were inspected on daily basis. Similarly, Harko [13] reviewed that ante mortem and pre slaughter examinations undertaken in Ethiopian abattoirs. However, meat inspector in abattoir at Haramaya University community service did not apply carcass certification. This might be due boneless carcasses transported to restaurant directly, which applied for different municipality and export abattoir in Ethiopia.

\subsection{Beef Marketing in University}

There was about more than 20 restaurants in Haramaya University owned by University and private for serving the community of campus through prepared sauce. The only staff launch was provided raw meat for staff members only. The enterprise sold by $80 \mathrm{~kg}$ / birr for student cafeteria service and $100 \mathrm{~kg} / \mathrm{birr}$ for staff restaurant and individual/ private restaurants as well as individual campus residency. This is good subsidize price for residence from Haramaya University because; when the current result compared with [18] it decreased by about $50 \%$.

\section{Conclusion and Recommendation}

The study was conducted at Haramaya University hundred day's beef fattening station and in the university Abattoir. The study directed through personal observation and developed question about the management practice and slaughtering procedure in abattoir through asking the workers and observation of the farm and abattoir. As per the information animal for fattened have been delivered from different zone by cooperatives of Tullu Dambir, Haramaya and Oda Bultum Union from: Chalanko, Haramaya and Badessa respectively. The cattle bought only through weigh based by some limitation on Weight, Appearance, Sex, and Age. Before stating fattening program quarantine for 15 days. The fatting program was conducted under the shade for hundred days. The major feed supplied for fattening were roughage which cafeteria leftover, crop residue collected from crop research and hay. When cattle finished from fattening they sent to slaughterhouse, however the University has not standardized abattoir. Which has limited in facilities and monitoring from higher campus administration? Their animal slaughtering procedure is cruel. The equipment used for slaughtering was not updated; the hammer and axes for stunning purposes which make animal suffer for more pain and stress and results defects the products. Other problems observed in the abattoir were poor hygienic, waste disposal, hide management, slaughtering, and procedures seen as malpractice with in slaughterhouse.

\section{Recommendations}

During cattle selection for fattening age, management practice and breeds considerations important for design different research and know the feed conversion efficiency.

Made ration formulation was important for feeding; because different fatting stage need different feed quality and quantity.

The station and the abattoir should work closely in collaboration with the scientific communities found in the University to improve the production system and to supply quality beef.

Periodic cleaning and sanitation, which includes disinfection of slaughterhouse premises and equipment, should consider as one of the most important activities in the abattoir.

\section{Acknowledgements}

The authors are thankful for all farm members from manager to individual works to assist and generate the information during this study conducted.

\section{References}

[1] Duguma Belay, Yisehak. K, Geert. PJJ, 2011. Analysis of constraints facing urban dairy farmers and gender responsibility in animal management in Jimma Town. Journal of Basic Applied Science 3:13-318.

[2] Ehui, S. Jabbar, M., Kiruthu, S., \& Gebremedhin, B. (2002). Essential actions to meet quality requirements of hides and skins and semi processed leather from Africa: A report prepared for the common fund for commodities (pp. 7-52). Amsterdam, The Netherlands.

[3] Shapiro, B. I., Gebru, G., Desta, S., Negassa, A., Nigussie, K., Aboset, G. and Mechal, H. 2015. Ethiopia livestock master plan. ILRI Project Report. Nairobi, Kenya: International Livestock Research Institute (ILRI).

[4] EMDIDI (Ethiopian Meat and Dairy Industry Development Instit 2016. Ethiopian Agro-Industry Strategy Meat Industry Sub-Sector Strategic Plan (2015-2025). Addis Ababa-Ethiopia.

[5] Scholtz M. M. 2007. Improvement of meat quality in commercial beef and pork production systems. SA-ANIM SCI 2007, vol 8: http://www.sasas.co.za/Popular/Popular.html.

[6] NebiHusein. 2018. Assessment of Beef Cattle Production and Marketing Practice at Mahabuba Farm in Harar, Ethiopia. Food Science and Quality Management, 82: 2224-6088.

[7] World Bank, 2004. Confidential document of the World Bank. Ethiopia: country economic. Memorandum. Background report: analysis of high-value exports, A Review of Manufacturing activities with high-value exports growth potential in Ethiopia. Draft April 2004.

[8] Haramaya University. 2017. About University. Retrieved April 23, 2017, from http://www.haramaya.edu.et/about/. 
[9] AOAC. 2000. Official Methods of Analysis. 17th Edition, The Association of Official Analytical Chemists, Gaithersburg, MD, USA. Methods 925.10, 65.17, 974.24, 992.16.

[10] Van Soest P. J., Robertson J. B., Lewis B. A. 1991: Methods for dietary fiber, neutral detergent fiber, and nonstarch polysaccharides in relation to animal nutrition. J. Dairy Sci., 74, 3583-3597.

[11] Dadi, G., Urge, M., Teklebrhan, T. 2017. Assessment of Commercial Beef Cattle Fattening Practices and performance in East Shoa Zone. Int J AgricSc Food Technol 3 (3): 067-076. DOI: http://doi.org/10.17352/2455-815X.000025.

[12] Tasfaye Moroda. 2016. Assessment of beef cattle production, management practices and marketing system in Lumedistrict East Shoa, Ethiopia. MSc Thesis Hawasa University.

[13] Harko Halala. 2015. Review of Beef Cattle Value Chainin Ethiopia. Journal of Industrial Engineering Letters, 5 (7): 2225-0581.

[14] Yidnekachew Alemayehu, Asmera Adicha, Mesfin Mengistu and Binyam Eshetu. 2016. Assessments of market Oriented beef cattle fattening System under farmer management condition in South Omo zone of SNNPR. Current Research in Agricultural Sciences, 3 (2): 21-45.

[15] Birmaduma Gadisa, Yesihak Yusuf, Mohammad, Y. Kurtu. 2019. Assessment of Beef Cattle Production and Marketing Practice in Eastern Oromia, Ethiopia. Journal of Food Science and Quality Management, Vol. 85: DOI: 10.7176/FSQM.

[16] Troy, D. J. and Kerry, J. P. 2010. Consumer Perception and the Role of Science in the Meat Industry. Meat Science, 86: 214 226.

[17] Lee, S. H., Choe, J. H., Choi, Y. M., Jung, K. C., Rhee, M. S., Hong, K. C., K., Ryu, Y. C. and Kim, B. C. 2012. The influence of pork quality traits and muscle fiber characteristics on the eating quality of pork from various breeds. Meat Science, 90:284-291.

[18] Birmaduma Gadisa. 2018. Analysis of Eating Qualities, Perception of Stakeholders on Beef Qualities Determinants and Commercial Value of Meat Cuts in Eastern Oromia, Ethiopia. Msc. Thesis Haramaya University, Ethiopia.

[19] Josefine Jerlström. 2013. Animalwelfare in Ethiopia: transport to and handling of cattleat markets in Addis Ababa and Ambo. Swedish University of agricultural sciences, department of animal nutrition and management, 461.

[20] Warriss, P. D., 2003. Meat science: An introductory text. CAB-International: England: Wallingford.

[21] Ekiz, B., Ekiz, E. E., Kocak, O., Yalcintan, H. \& Yilmaz, A., 2012. Effect of pre-slaughter management regarding transportation and time in lairage on certain stress parameters, carcass and meat quality characteristics in Kivircik. Meat Sci. 90, 967-976.

[22] Muchenje, V., Dzama, K., Chimonyo, M., Strydom, P. E. \& Raats, J. G., 2009. Relationship between pre-slaughter stress responsiveness and beef quality in three cattle breeds. Meat Sci. 81, 653-657.

[23] FAO, OIE \& WB. 2010. Good Practices for Biosecurity in the Pig sector: Issues and Options in Developing and Transition Countries. FAO Animal Production and Health Paper No. 169. Rome FAO.

[24] GemechuTaffa, 2015. Determination of Haramaya University Beef Cattle Feeds Chemical Composition and an Overviews of Available Resource, BSc. Senior Research unpublished paper. Haramaya University, Haramaya.

[25] Muchakilla, M. Asimwe, L., Kimambo, A. E., Mtenga, L. A. Laswa, G. H. 2014. Effect of diet and muscle type on meat quality characteristics of Tanzania Shorthorn Zebu. Livestock Research for Rural Development, 26 (10). Retrieved January 11, 2018, from http://www.lrrd.org/lrrd26/10/much26186.html.

[26] ZGAJNAR, J. and S. KAVCIC, 2008. Optimization of bulls fattening ration applying mathematical deterministic programming approach. Bulg. J. Agric. Sci., 14: 76-86.

[27] Khan, Muhammad Issa, Cheorun Jo, and Muhammad RizwanTariq. 2015. "Meat FlAvorPrecursors and Factors in FlUencingFlAvor Precursors A Systematic Review." MESC 110.

(2015):278-84 https://doi.org/.1016/j.meatsci.2015.08.002.

[28] Morgan, N and G. Tallard, 2006. Background paper for the Competitive Commercial Agriculture in Sub-Saharan Africa (CCAA) Study. Cattle and beef international commodity profile, Food and Agriculture Organization. Rome, Italy.

[29] APO. 2005. Quality control for processed foods. Report of the APO Seminar on Quality Control for Processed Food held in the Republic of China, 8-14 May 2002.

[30] FAO (Food and Agriculture Organization). 2004. Guidelines for humane handling, transport and slaughter of livestock, Edited by: Gunter Heinz. RAP Publication.

[31] Chulayo, A. Y., Tada, O. and Muchenje, V. 2012. Research on pre-slaughter stress and meat quality: A review of challenges faced under practical conditions. Applied Animal Husbandry \& Rural Development 2012, Volume 5, South Africa.

[32] Cortesi, M. X. 1994 Slaughterhouse and Humane treatment. Rev Sci Tech offintEpiz 13: 171-193.

[33] FAO (Food and Agriculture Organization). 2008. Food Energy - Methods of Analysis and Conversion Factors and Analytical Methods for Proteins in Foods. Italy, Rome.

[34] Ministry of Agriculture. 2010. "Meat Transport and Storage Guideline." Meat Transport and Storage Guideline (for Abattoir and Airport Cargo Terminal Workers) Ii.

[35] Fagerlund, A., Møretrø, T., Heir, E., Briandet, R., Langsrud, S. 2017. Cleaning and Disinfection of Biofilms Composed of Listeria monocytogenes and Background Microbiota from Meat Processing Surfaces. Appl Environ Microbiol. 2017; 83 (17): doi: 10.1128/AEM.01046-17. 